\title{
TANGGUNG JAWAB DAN RESPONSIVITAS BIROKRASI PEMERINTAHAN DALAM PELAYANAN PUBLIK DI KOTA MAKASSAR (Studi Kasus Pelayanan Ijin Mendirikan Bangunan (IMB) di Dinas Tata Ruang dan Bangunan Kota Makassar)
}

\author{
Delly Mustafa \\ Fakultas Ilmu Sosial dan Ilmu Politik UPRI Makassar \\ Email: Delly.mustafa0906@gmail.com
}

\begin{abstract}
ABSTRAK
Konsep birokrasi pemerintahan berkaitan erat dengan peran dan fungsi organisasi pemerintahan yang besar dalam rangka peningkatan kualitas pelayanan kepada masyarakat. Pelayana yang berkualitas adalah pelayanan yang harus diikuti dengan tanggung jawab dan respon oleh aparat birokrasi dalam menjalankan tugasnya sebagai provider. Sejalan dengan hal tersebut Denhard and Denhard (2003) dengan model pelayanan new public service menekankan bahwa pelayanan publik harus responsif terhadap berbagai kepentingan dan nilai-nilai publik yang ada. Dalam konteks pelayanan publik, akuntabilitas adalah suatu ukuran yang menunjukkan seberapa besar tingkat kesesuaian penyelenggaraan pelayanan dengan ukuran nilai atau norma eksternal yang ada di masyarakat atau yang dimiliki oleh para stakeholders. Sedangkan responsivitas birokrasi pemerintahan menjadi sangat dibutuhkan masyarakat ketika masyarakat membutuhkan pelayanan perizinan yang berkualitas.

Hasil penelitian menunjukkan bahwa tanggung jawab birokrasi pemerintahan sudah dilaksanakan dengan baik, walaupun masih sebatas pada tanggung jawab pada makna acountability, dan belum disertai tanggung jawab pada makna obligasi dan makna cause.kemudian pada aspek responsivitas, masyarakat belum merasakan pelayanan yang baik dari birokrast masyarakat mengeluh terhadap layanan yang diberikan birokrat karena masih adanya praktek diskriminasi dalam pemberian pelayanan.
\end{abstract}

Kata Kunci: Tanggung jawab, Responsivitas, Birokrasi Pemerintahan, dan Pelayanan Publik

\section{PENDAHULUAN}

Undang-Undang Republik Indonesia Nomor. 25 Tahun 2009 tentang pelayanan publik menjelaskan "bahwa negara berkewajiban melayani setiap warga negara dan penduduk untuk memenuhi hak dan kewajiban dasarnya dalam kerangka pelayanan publik yang merupakan amanat UUD RI 1945.” Dijelaskan pula dalam Undang-Undang Republik Indonesia Nomor, 25 Tahun 2009 pada bagian kesatu Bab II Pasal 2, undang-undang pelayanan publik dimaksudkan untuk memberikan kepastian hukum dan hubungan antara masyarakat dan penyelenggara dalam pelayanan publik.

Birokrasi pemerintahan dituntut harus mampu memberikan pelayanan yang sebaik mungkin kepada masyarakat. Pelayanan yang baik dan berkualitas dapat terpenuhi apabila birokrat sebagai pelayanan publik bertanggung jawab dalam mengemban tugas pelayanan, dan merespon setiap keluhan-keluhan yang dilontarkan masyarakat. Dengan demikian 
tanggungjawab dan responsivitas sebaiknya dimiliki setiap birokrat sebagai pelayanan publik.

Dalam penelitian tentang pelayanan publik, peneliti menfokuskan pada pelayanan Izin Mendirikan Bangunan di Kota Makassar yang dilakukan oleh birokrasi pemerintahan, dimana dalam konteks pelayanan Izin Mendirikan Bangunan, birokrasi pemerintahan dituntut harus mampu memberikan pelayanan yang sebaik mungkin kepada masyarakat, seperti yang tertuang dalam peraturan Walikota Makassar Nomor 14 Tahun 2005 tentang Tata Cara Pemberian Izin pemerintah Kota Makassar, dimana dalam Bab 1 Pasal 1 yang tertuang dalam peraturan daerah Kota Makassar No. 15 Tahun 2004 dijelaskan bahwa Ijin Mendirikan Bangunan (IMB) adalah salah satu bentuk perizinan untuk membangun (merenovasi) bangunan (rumah, gedung, dan lainnya) yang dikeluarkan oleh pemerintah untuk masyarakat, yang proses pelayanannya diselenggarakan oleh Dinas Perizinan dan melalui Kantor Dinas Tata Ruang dan Bangunan.

Dalam memberikan pelayanan Izin Mendirikan bangunan, birokrat dituntut untuk bertanggung jawab dan merespon setiap keluhan- keluhan yang dilontarkan masyarakat yang mengurus IMB, hal ini perlu dilakukan oleh karena pelayanan yang baik akan memberikan kepuasan kepada masyarakat.

Berdasarkan Hasil pengamatan dan hasil wawancara terhadap beberapa orang masyarakat yang mengurus Surat Ijin Mendirikan Bangunan, ternyata pada umumnya mereka mengeluh terhadap proses pelayanan yang diberikan oleh birokrat sebagai pelayan publik. Keluhankeluhan tersebut berkaitan dengan; besarnya Biaya Pengurusan surat IMB yang tidak sesuai lagi dengan biaya standar yang ada, adanya calo dikalangan birokrat sendiri yang menawarkan diri untuk mengurus surat IMB, penundaan pekerjaan pelayanan, adanya diskriminasi pelayanan, aparat birokrasi yang kurang ramah, dan kurang menampakkan tanggung jawab, kurangnya rasa responsifitas dalam memberikan pelayanan, dan adanya pilih kasih dalam memberikan pelayanan kepada masyarakat.

Keluhan masyarakat terhadap proses pelayanan yang dilakukan aparat birokrasi yang dikemukakan di atas, merupakan kondisi empirik bahwa birokrasi pemerintahan dalam memberikan pelayanan kepada masyarakat belumlah optimal. Di sisi lain aspek pelayanan yang berkualitas merupakan hal penting dalam menumbuhkan kepercayaan masyarakat terhadap birokrasi pemerintahan.

\section{KAJIAN TEORI}

\section{Konsep Birokrasi Pemerintahan}

Dalam konteks Indonesia, perkembangan birokrasi di indonesia, tidak terlepas dari faktor kesejarahan, apa yang dicapai birokrasi sekarang ini merupakan perjalanan sejarah yang panjang, walaupun sejarah tidak pernah berulang kembali, namun dengan menggunakan secara seksama fakta sejarah akan diperoleh perhatian yang lebih cepat mengenai fakta yang ada sekarang ini. Sejarahpun akan membantu perspektif masa depan, apa saja yang telah dilakukan oleh administrasi publik dapat melacak jejak birokrasi yang dilakukan oleh administrasi publik, mulai zaman kerajaan yang masyarakatnya masih sangat sederhana, masa kolonial sampai dengan setelah kemerdekaan yang masyarakatnya relatif modern. Selain itu, variabel lain yang juga mempengaruhi eksistensi perjalanan birokrasi di Indonesia adalah faktor kepentingan politik (political interest).

Sejarah perjalanan panjang birokrasi tersebut di atas, telah banyak mewarnai kehidupan pemerintahan dan masyarakat, keberadaannya sebagai instrumen pemerintah dalam menterjemahkan dan mengimplementasikan kebijakan pemerintah serta sebagai pelayan rakyat, 
menjadi suatu kebutuhan, karena itu, kehadirannya tak dapat terelakkan. Kehadiran birokrasi pemerintahan merupakan sebuah konsukuensi logis diterimanya hipotesis bahwa pemerintah mempunyai misi suci yaitu untuk melayani, memberdayakan dan mensejahterahkan rakyatnya. Atas dasar pemahaman yang demikian itulah maka pemerintah harus terlibat langsung dalam memproduksi barang dan jasa publik yang diperlukan oleh rakyat, serta pada saat yang sama mendistribusikan secara cepat, tepat dan adil kepada rakyatnya. Pemerintah secara aktif terlibat dalam kehidupan sosial rakyat, bahkan jika perlu pemerintah memutuskan apa yang terbaik bagi rakyat. Untuk mengemban misi suci tersebut maka pemerintah membangun dan membutuhkan suatu institusi yang bertujuan untuk melayani kepentingan rakyat yang disebut "birokrasi pemerintahan".

Dalam upaya pelayanan dan mewujudkan kesejahteraan rakyat, birokrasi pemerintahan memberikan andil yang besar. Segala aktifitas penyelenggaraan pemerintahan tidak terlepas dari konteks public services dan public affairs. Barang dan jasa publik harus dapat dikelola secara istimewa, efisien dan efektif serta profesional, dan dapat diterima oleh rakyat dengan baik. Kualitas dan konsekuensi proses ini menjadi tanggung jawab birokrasi pemerintahan, artinya bahwa peran pemerintah yang strategis serta efektif dari peran tersebut akan banyak ditopang oleh bagaimana birokrasi pemerintahan yang mampu melaksanakan tugas dan fungsinya secara profesional dan bertanggung jawab.

Secara konseptual, Ndraha (2003: 521) berpendapat bahwa:

Birokrasi pemerintahan didefinisikan sebagai struktur pemerintahan yang berfungsi memproduksi jasa publik atau layanan civil tertentu berdasarkan kebijakan yang ditetapkan dengan mempertimbangkan berbagai pilihan dari lingkungan.

\begin{abstract}
Birokrasi pemerintahan adalah sistem yang mengatur jalannya pemerintahan dan pembangunan. Sebagai suatu sistem, proses birokrasi mencakup berbagai subsistem yang saling berkaitan, saling mendukung, dan saling menentukan, sehingga dapat membentuk totalitas komponen yang terpadu. Subsistem tersebut mencakup kewenangan, tugas pokok, unsur manusia, biaya, tempat kerja dan tata kerja.
\end{abstract}

\section{Konsep Pelayanan Publik}

Pelayanan publik diturunkan dari makna public service, yang berarti; berbagai aktifitas yang bertujuan memenuhi kebutuhan masyarakat akan barang dan jasa (Pamudji, 1999 dalam Napitupulu, 2007: 165). Definisi public service yang dikemukakan Pamudji, oleh Soetopo (dalam Napitupulu,2007: 165) diartikan sebagai Pelayanan umum, yaitu segala bentuk kegiatan pelayanan yang dilaksanakan oleh instansi pemerintah di pusat, di daerah dan lingkungan BUMN/D dalam bentuk barang dan atau jasa, baik dalam rangka pemenuhan kebutuhan masyarakat maupun dalam rangka pelaksanaan perundang-undangan.

Secara konseptual, pelayanan publik menurut Subarsono (2006: 136) adalah serangkaian aktifitas yang dilakukan oleh birokrasi publik untuk memenuhi kebutuhan warga pengguna. Pengguna yang dimaksudkan adalah warga negara yang membutuhkan pelayanan publik.

Dengan mengacu pada pemikiran para ahli di atas, maka dapat dikemukakan bahwa pelayanan publik merupakan proses pemenuhan kebutuhan dan solusi atas berbagai permasalahan yang menyertai kehidupan masyarakat setiap saat oleh pemerintah atau birokrasi pemerintahan berupa barang dan jasa yang disediakan dan diberikan ketika masyarakat membutuhkan atau sebelum mereka meminta. 
Selain teori-teori pelayanan yang dikemukakan di atas, Denhard and Denhard (2003: 25-26) menawarkan suatu model pelayanan yang disebutnya dengan "model pelayanan publik baru" (new public service). Dijelaskan bahwa model pelayanan new public service, pelayanan publik berpijak pada teori demokrasi yang mengajarkan adanya egaliter dan persamaan hak di antara warga negara. Dalam model ini, kepentingan publik dirumuskan sebagai hasil dialog dari berbagai nilai yang ada di dalam masyarakat, bukan dirumuskan oleh elite politik seperti yang tertera dalam aturan. Dalam model ini ditegaskan bahwa birokrasi yang memberikan pelayanann publik harus bertanggungjawab kepada masyarakat secara keseluruhan.

Dalam model ini, birokrasi publik bukan hanya sekedar harus akuntabel pada berbagai aturan hukum, melainkan juga harus akuntabel pada nilai-nilai yang ada dalam masyarakat, norma politik yang berlaku, standar profesional, dan kepentingan warga negara. Hal tersebut merupakan serangkaian konsep pelayanan publik yang ideal masa kini di era demokrasi.

Dasar teoritis pelayanan publik yang ideal menurut paradigma new public service, yaitu pelayanan publik harus responsif terhadap berbagai kepentingan dan nilai-nilai publik yang ada. Napitupulu (2007: 165) mendefinisikan pelayanan publik adalah; segala bentuk kegiatan pelayanan yang dilaksanakan oleh instansi pemerintah di pusat, di daerah dan di lingkungan BUMN/D dalam bentuk barang dan atau jasa, baik dalam rangka pemenuhan kebutuhan masyarakat maupun dalam rangka pelaksanaan perundangundangan.

Keputusan Menteri pendayagunaan Aparatur Negara Nomor 63 Tahun 2003, mendefinisikan "pelayanan publik sebagai segala bentuk jasa pelayanan, baik dalam bentuk barang publik maupun jasa publik yang pada perinsipnya menjadi tanggung jawab dan dilaksanakan oleh instansi pemerintah di pusat, di daerah, dan di lingkungan Badan Usaha Milik Negara atau Badan Usaha Milik Daerah, dalam rangka upaya pemenuhan kebutuhan masyarakat maupun dalam rangka pelaksanaan ketentuan peraturan perundang-undangan."

\section{Kualitas Pelayanan Publik}

Kebutuhan manusia (human needs) adalah suatu rasa yang timbul secara alami dari dalam diri manusia untuk memenuhi segala sesuatu yang diperlukan dalam kehidupannya. Kebutuhan-kebutuhan ini kemudian memunculkan keinginan manusia (human wants) untuk memperoleh sesuatu yang dibutuhkan dalam kehidupannya.

Kebutuhan manusia bermacammacam, ada yang bisa dipenuhinya melalui mengadakan sendiri, diupayakan sendiri dengan bantuan pihak lain atau masyarakat, dan yang memang harus diperoleh dari pihak lain. Kebutuhan yang diperoleh dari pihak lain menurut Ndraha (2003: 55) pemenuhannya melalui pasar (private choice), dan pemenuhannya melalui proses istimewa. Lebih lanjut Ndraha menyatakan bahwa, proses secara istimewa itu harus seefisien mungkin, seproduktif mungkin, seterbuka mungkin, sehingga biaya dan tarif (harga) serendah mungkin, seterjangkau mungkin oleh konsumer.

Pemenuhan kebutuhan manusia yang dilakukan secara istimewa tersebut dilakukan oleh badan publik sehingga jenis pelayanannya juga merupakan pelayanan kepada publik atau masyarakat (publik service), dengan kata lain, pemerintah melalui badan publik bertindak sebagai provider, sedangkan masyarakat yang meminta akan kebutuhan pelayanan disebut sebagai consumer atau pengguna (user). Pemerintah melalui badan publiknya sebagai penyedia layanan (service provider), dalam melaksanakan kegiatannya tidak bertujuan komersil atau kegiatan yang tidak bermotifkan mencari 
laba atau disebut juga usaha nirlaba (nonprofit motive). Sedangkan penerima layanan (consumer) yang termasuk kelompok pelanggan kegiatan non komersil yang sifat layanannya cuma-cuma atau dengan mengeluarkan pembayaran yang sepadan dengan manfaat yang diperolehnya (konstribusi pengganti).

Provider dalam memberikan layanan kepada masyarakat menuntut terjadinya proses pelayanan yang berkualitas. Dalam kamus yang disusun Wojowarsito, "quality adalah kualitas, mutu, kecakapan, sifat, macam, jenis". Sedangkan yang dikutip dalam Ndraha (2005: 83), quality adalah "characteristics, properti or attitude, character or nature". Dengan kata lain, setiap orang, barang atau zat memiliki kualitas, dan kualitas ini membedakan antara orang, barang atau zat yang satu dengan lainnya.

Pelayanan yang diberikan kepada masyarakat itu menuntut kualitas. Pelayanan yang diselenggarakan oleh pemerintah melalui aparatnya, walaupun tidak bertujuan untuk mencari keuntungan namun tetap harus mengutamakan kualitas pelayanan yang sesuai dengan tuntutan, harapan dan kebutuhan masyarakat yang dilayani. Para aparat (pegawai) haruslah menyadari posisi dan peran mereka sebagai pelayan publik. Bila dimata masyarakat kesan yang muncul tidak demikian, berarti tugas pelayanan yang diterima selama ini bukanlah produk pelayanan yang sepenuh hati, melainkan pelayanan yang hanya didasari oleh kewajiban sebagai abdi negara.

Selanjutnya, Lukman (2003: 10) mencirikan kualitas pelayanan sebagai suatu kegiatan pelayanan yang diberikan kepada pelanggan sesuai dengan prinsip lebih murah, lebih baik, cepat, tepat, akurat, ramah, sesuai dengan keinginan pelanggan.

Lebih ditegaskan lagi dengan dikeluarkannya Keputusan Menteri Pendayagunaan Aparatur Negara (PAN) momor 81 tahun 1995 yang menegaskan bahwa pelayanan yang berkualitas hendaknya sesuai dengan sendi berikut: 1) Kesederhanaan, 2) Kejelasan dan kepastian, 3) Keamanan, 4) Keterbukaan, 5) Efisien, 6) Ekonomis, 7) Keadilan yang merata, dan 8) Ketetapan waktu;

Dari pemahaman tersebut, maka Pelayanan yang dilakukan harus ada kejelasan dan kepastian hukum, serta tanggung jawab pelayanan untuk kebutuhan konsumer/masyarakat, bukan untuk kebutuhan pegawai selaku pemberi layanan.

\section{Tanggung jawab birokrasi pemerintahan}

Djohan dan Milwan (2007: 27) berpendapat bahwa tanggung jawab adalah norma yang menuntut kesediaan moral setiap penyelenggara negara untuk: (1) melaksanakan tugas, wewenang dan kewajibannya secara profesional dan tekad untuk terus menerus meningkatkan mutu profesionalitasnya; (2) kehati-hatian dan kecermatan dalam setiap sikap, prilaku, tindakan maupun ucapannya, baik di dalam lingkungan kerjanya maupun diluar lingkungan kerja; (3) memikul akibat resiko dan tanggung jawab yang terpaut pada kedudukan, kewenangan dan tugas yang dilaksanakannya; (4) kewajiban untuk mengakui kesalahannya, bersedia untuk mengakui kesalahannya, bersedia untuk memperbaiki kesalahannya secepat mungkin dan memikul akibat dari perilaku, tindakan keputusan dan ucapan yang salah.

Menurut Hasibuan (1989: 70), tanggungjawab tercipta karena penerimaan wewenang. Tanggungjawab harus sama dengan wewenang yang dimiliki. Dengan demikian tanggung jawab timbul karena adanya hubungan antara atasan dan bawahan (superior - subordinate relationship).

Pendapat di atas menunjukkan bahwa tanggung jawab birokrasi pemerintahan dalam memberikan pelayanan kepada masyarakat mencakup beberapa hal yaitu tanggungjawab dalam mengemban tugas pelayanan kepada masyarakat secara profesional, dalam 
konteks berkualitas, memenuhi kebutuhan dan menjawab permasalahan, tanggungjawab dalam mempertanggungjawabkan tugasnya termasuk dampak negatif, yang timbul ataupun kegagalan dalam proses pelayanan, serta tanggung jawab dalam mengakui kesalahan secara ikhlas dan bersedia untuk meningkatkan kualitas pelayanan kepada masyarakat.

Keikhlasan dalam memberikan pelayanan kepada masyarakat adalah berkaitan dengan tingkat ketaatan aparat terhadap ketentuan dan paraturan. Ketaatan kepada ketentuan dan peraturan dalam birokrasi, yang merupakan norma khusus (Keraf, 2005: 18), dan berlaku dalam bidang kegiatan tertentu di mana masyarakat maupun pegawai harus patuh selama terkait dengan aktifitas organisasi publik, namun, keikhlasan, selain kepatuhan ketentuan dan peraturan, yang di dalamnya termasuk sopan santun yang menyangkut sikap lahiriah manusia, dapat mengungkap "sikap hati" apabila memiliki kualitas moral, dan merupakan tolok ukur yang dipakai masyarakat untuk mengukur kebaikan seseorang.

Dengan demikian, keikhlasan dalam memberikan pelayanan kepada publik walaupun tidak masuk pada kategori dimensi pertanggungjawaban (acountability), sebaiknya selalu terpatri pada diri birokrat sebagai pelayan publik. Pada Dimensi acountability yang hanya menyoroti keharusan bagi eksekutif atau pihak yang diserahi tugas untuk melaporkan kembali apa yang telah ditugaskan sesuai dengan apa yang tertulis, di luar yang tidak tertulis tidak dijadikan materi pertanggungjawabannya. Hal itu berarti, melalui acountability, pemerintah harus mempertanggungjawabkan perintah dan wewenangnya kepada pemberi perintah dan sumber wewenang.

Selain "makna acountability, pertanggungjawaban atau responsible goverment masih lebih luas lagi, yakni mencakup obligation dan makna cause sebagaimana (Spiro, 1969: 14-20), melalui obligation, pemerintah berkewajiban mempertanggungjawabkan segala hal yang berhubungan dengan pelaksanaan tugasnya, baik yang akan dilakukan maupun yang sudah dilakukan, baik yang tertulis maupun yang tidak tertulis, baik diminta maupun tidak diminta kepada seluruh masyarakat. Selanjutnya makna cause dimaksudkan : tanggungjawab pemerintah baik eksekutif maupun legislatif kepada rakyat atas segala akibat yang ditimbulkan oleh keputusan batinnya yang bersifat free choice sehingga ia bertindak dan membawa akibat tertentu kepada masyarakat dan lingkungannya

\section{Responsivitas Birokrasi Pemerintahan}

Responsivitas adalah kemampuan birokrasi untuk mengenali kebutuhan masyarakat, menyusun agenda dan prioritas pelayanan, serta mengembangkan program pelayanan sesuai dengan kebutuhan dan aspirasi masyarakat. Resonsivitas mengukur daya tanggap birokrasi terhadap harapan, keinginan dan aspirasi, serta tuntutan pengguna jasa.

Responsivitas sangat diperlukan dalam pelayanan publik, karena hal tersebut merupakan bukti kemampuan organisasi untuk mengenali kebutuhan masyarakat, menyusun agenda dan prioritas pelayanan serta mengembangkan program-program pelayanan publik sesuai dengan kebutuhan dan aspirasi masyarakat (Dilulio dalam Dwiyanto, 2008: 63). Menurut Osborne \& Plastrik (dalam Dwiyanto, 2008: 62) bahwa; organisasi yang memiliki responsivitas rendah dengan sendirinya memiliki kinerja yang jelek juga. Dalam operasionalisasinya, responsivitas pelayanan publik dijabarkan menjadi beberapa indikator, yaitu: (1) terdapat tidaknya keluhan dan pengguna jasa selama satu tahun terakhir; (2) sikap aparat birokrasi dalam merespons keluhan dari pengguna jasa; (3) penggunaan keluhan dari pengguna jasa sebagai referensi bagi perbaikan penyelenggaraan pelayanan pada masa mendatang; (4) 
berbagai tindakan aparat birokrasi untuk memberikan kepuasan pelayanan kepada pengguna jasa; (5) penempatan pengguna jasa oleh aparat birokrasi dalam sistem pelayanan yang berlaku.

Smith (1985: 28) berpendapat bahwa; responsiveness adalah ability to provide what people demand. Maksudnya bahwa responsivitas merupakan kemampuan untuk menyediakan apa yang menjadi tuntutan masyarakat, pendapat ini sangat luas. Pandangan yang sama tetapi spesifik dikemukakan oleh Dwiyanto (2002: 60) yang mengatakan bahwa; responsivitas adalah kemampuan birokrasi pemerintahan untuk mengenali kebutuhan masyarakat, menyusun agenda dan prioritas pelayanan sesuai dengan kebutuhan dan aspirasi masyarakat, sehingga dapat dikatakan bahwa responsivitas disini menunjuk pada keselarasan antara program dan kegiatan pelayanan dengan kebutuhan dan aspirasi masyarakat. Responsivitas dimaksudkan sebagai salah satu indikator kinerja, karena responsivitas secara langsung menggambarkan kemampuan organisasi publik dalam menjalankan misi dan tujuannya, terutama untuk memenuhi kebutuhan masyarakat. Responsivitas yang rendah ditunjukkan dengan ketidakselarasan antara pelayanan dengan kebutuhan masyarakat. Hal tersebut jelas menunjukkan kegagalan organisasi dalam mewujudkan misi dan tujuan organisasi publik. Organisasi yang memiliki responsivitas rendah dengan sendirinya memiliki kinerja yang jelek pula.

Dalam konteks pelayanan kepada masyarakat, Lovelock dalam (Widodo, 2001: 272) berpendapat bahwa "responsivitas diartikan sebagai rasa tanggung jawab terhadap mutu pelayanan". Dengan demikian perilaku birokrasi pemerintahan yang responsif adalah kecepatan dan ketepatan seorang birokrat pemerintahan dalam mencermati, mengindentifikasi dan menanggapi dengan segera setiap kebutuhan dan permasalahan yang terjadi dalam masyarakat melalui perumusan kebijakan yang berpihak pada masyarakat (partiality) dan pelayanan yang berkualitas. Dengan demikian maka kehadiran birokrasi pemerintahan sebagai pelayan masyarakat akan lebih bermakna di tengah-tengah masyarakat sebagai pelanggan produk-produk pemerintah.

\section{METODE PENELITIAN}

Jenis penelitian yang digunakan adalah jenis penelitian kualitatif, Adapun Pendekatan Penelitian yang digunakan adalah Studi Kasus. Kasus dalam penelitian kualitatif dapat berupa individu, program, institusi, atau kelompok. Penelitian ini dilaksanakan pada salah satu lokus lembaga perizinan di Kota Makassar, yaitu; Dinas Tata Ruang dan Bangunan Kota Makassar. Adapun sumber data dalam penelitian ini menggunakan dua jenis data yaitu; data primer dan data sekunder dengan proporsi sesuai dengan tujuan yang hendak dicapai.

Teknik pengumpulan data, dilakukan melalui teknik wawancara dengan cara terstruktur, menggunakan pedoman wawancara (interview guide). Proses wawancara dilakukan melalui beberapa langkah: 1) wawancara terhadap masyarakat yang mengurus IMB yang dipilih secara purposive (sengaja) yang berjumlah 4 orang. Tujuan dari wawancara ini untuk memahami secara mendalam pendapat informan tentang pelayanan publik yang dilakukan birokrasi pemerintahan,. 2) Wawancara terhadap aparat birokrasi pemerintahan, yang bersentuhan langsung dengan pelayanan IMB, dan yang mengetahui persis dan terlibat secara langsung dalam proses penerbitan surat perizinan IMB yang dipilih secara purposive berjumlah 5 orang yaitu ; Kepala Dinas Tata Ruang dan Bangunan, Sekretaris Kepala Dinas, Kepala Bagian perizinan, Kepala Seksi Administrasi Perizinan, Kepala Seksi Penerbitan Izin, dilakukan secara langsung ke lokus penelitian. 
Penelitian ini menggunakan teknik analisis data kualitatif. Model analisis dengan menggunakan teknik kualitatif di desain sedemikian rupa sehingga dapat mengungkap persoalan penting yang terkait dengan fokus masalah yang telah ditetapkan. Aktifitas dalam analisis data kualitatif, yaitu: reduction (Reduksi data), display (Penyajian data), dan Verification (penarikan kesimpulan).

\section{HASIL DAN PEMBAHASAN}

Berdasarkan hasil penelitian bahwa sebagian dari birokrat yang bertugas sebagai pelayan masyarakat sudah cukup bertanggungjawab sesuai dengan tupoksi yang dimiliki, walaupun masih kurang responsif terhadap pengguna jasa pelayanan. Sikap yang mereka tampilkan didominasi dengan sikap sebagai orang yang dibutuhkan ketimbang sebagai orang yang sedang melaksanakan tugas menyediakan atau memberikan pelayanan. Keadaan ini dapat diamati dengan sikap membiarkan pengguna jasa berdiri beberapa saat didepan counter informasi, tanpa memberikan sapaan atau mengenali lebih dekat pengguna jasa akan kebutuhan yang diperlukan.

Sebagai birokrat yang bertanggungjawab, jika ada masyarakat pemohon IMB sudah berada di areal kantor, sebaiknya birokrat langsung meresponnya walaupun aparat tersebut sedang sibuk menyelesaikan pekerjaannya, inilah merupakan bentuk tanggung jawab sebagai abdi masyarakat.

Dengan kurang dibekali rasa tanggung jawab dan responsivitas, sehingga kesan petugas layanan terlihat kaku (rigit), walaupun situasi dilematis sedang dialami petugas layanan tersebut karena disatu sisi sedang menyelesaikan pekerjaan membenahi berkas yang diajukan pengguna jasa sebelumnya, sedangkan disisi lainnya, pekerjaan untuk memberikan pelayanan selanjutnya kepada pengguna jasa berikut sudah menunggu dihadapannya.
Kondisi yang dilakukan petugas tersebut di atas, sebenarnya memiliki sisi baik, jika dilihat dari aspek administrasi, dengan menyelesaikan satu (persoalan) pekerjaan sebelum memulai pekerjaan berikutnya, ini biasanya telah menjadi ketentuan organisasi untuk segera menyelesaikan tugas-tugas yang menjadi tanggungjawabnya, namun ketentuanketentuan pelaksanaan tugas tersebut tidak dapat diartikan secara kaku, tetapi perlu kemampuan menterjemahkan ke dalam bahasa pelayanan yang baik, yang mana pengguna jasa adalah juga sebagai manusia yang butuh perlakuan secara manusiawi.

Untuk lebih jelasnyua tentang kedua aspek yaitu aspek tanggung jawab dan aspek responsivitas, penulis akan memaparkan secara rinci dari hasil penelitian sebagai berikut:

\section{Tanggung Jawab Birokrasi Pemerintahan}

Perilaku birokrasi pemerintahan yang bertanggungjawab dalam memberikan pelayanan Izin Mendirikan Bangunan di Kota Makassar merupakan suatu kebutuhan masyarakat. Pelayanan perizinan yang berkualitas tidak akan dapat terwujud jika tidak disertai dengan perilaku birokrasi pemerintahan yang bertanggung jawab. Tanggung jawab yang dimaksud adalah pelaksanaan tugas seorang birokrat dalam pelayanan seharihari, yang dijalaninya sesuai dengan aturan, tepat waktu, dan dapat menyelesaikan tugas pelayanan perizinan dengan baik dan benar serta dapat menanggung resiko terhadap berbagai permasalahan dalam pelayanan perizinan. Intinya adalah birokrasi pemerintahan hadir pada saat rakyat membutuhkannya.

Dalam konteks pelayanan publik, akuntabilitas adalah suatu ukuran yang menunjukkan seberapa besar tingkat kesesuaian penyelenggaraan pelayanan dengan ukuran nilai atau norma eksternal yang ada di masyarakat atau yang dimiliki oleh para stakeholders. 
Nilai dan norma pelayanan yang berkembang dalam masyarakat tersebut diantaranya meliputi transparansi dalam pelayanan, keadilan, kepastian, ketepatan waktu, jaminan penegakan hukum, hak azasi manusia dan orientasi pelayanan yang dikembangkan bagi masyarakat pengguna jasa.

Pemerintahan yang bertanggung jawab berarti adanya pola, bentuk dan mekanisme pertanggungjawaban tertentu dari pemerintah kepada masyarakat sebagai pemilik negara, pemegang kekuasaan negara, sehingga terjadi dalam suatu hubungan pemerintahan, hubungan antara yang diperintah dengan yang memerintah.

Makna pertanggungjawaban yang demikian, hanyalah salah satu dimensi dari konsep pertanggungjawaban, yakni dari dimensi acountability. Dimensi pertanggungjawaban ini hanya menyoroti keharusan bagi birokrat yang diserahi tugas untuk melaporkan kembali apa yang telah ditugaskan sesuai dengan apa yang tertulis, di luar yang tidak tertulis tidak dijadikan materi pertanggungjawabannya. Hal itu berarti, melalui acountability, pemerintah harus mempertanggungjawabkan perintah dan wewenangnya kepada pemberi perintah dan sumber wewenang.

Perilaku birokrat yang bertanggungjawab pada prinsipnya menjawab dua aspek utama dari responsible goverment, yang telah menunjukkan hakekat dari isi tanggung jawab kepada masyarakat. Hakekat responsible goverment, yaitu makna obligation dan makna cause. Melalui makna obligation, pemerintah berkewajiban mempertanggungjawabkan segala hal yang berhubungan dengan pelaksanaan tugasnya, baik yang akan dilakukan maupun yang sudah dilakukan, baik yang tertulis maupun yang tidak tertulis, baik diminta maupun tidak diminta kepada seluruh masyarakat.

$$
\text { Sejauh ini, }
$$

model pertanggungjawaban sebagai obligation jarang dipraktekkan oleh aparat pemerintahan disemua instansi pemerintahan. Hal tersebut senada dengan yang diungkapkan informan Thomas, yang mengatakan bahwa tanggung jawab yang dilakukan oleh aparat pelayanan sudah dilakukan, tetapi masih terbatas pada tanggung jawab sebagai accountability saja, karena petugas pelayanan Cuma bertanggung jawab atas apa yang dilakukan secara administrasi pada hari itu, tetapi untuk seterusnya petugas layanan Cuma membuat janji dalam penyelesaian surat ijin tersebut, sehingga kondisi ini menurut hemat penulis, bahwa birokrat sudah melaksanakan tanggungjawabnya sesuai tupoksi yang dimiliki, walaupun masih sebatas pada tanggung jawab dari dimensi acountabiliy, tetapi belum menyentuh secara penuh tanggung jawab pada dimensi obligation dan cause.

Dalam kaitan dengan pelayanan perizinan, makna tanggungjawab sebagai obligation memang perlu dipraktekkan dalam pelayanan perizinan kepada masyarakat karena manyangkut kepuasan masyarakat. Tanggungjawab yang dilakukan bukan hanya sekedar melaporkan hasil kerja administrasi belaka tetapi harus lebih bersifat tanggungjawab moral.

Tanggung jawab sebagai cause dimaksudkan sebagai tanggung jawab birokrat pemerintahan kepada masyarakat atas segala akibat yang ditimbulkan oleh keputusan hatinya yang bersifat free choice sehingga ia bertindak dan membawa akibat tertentu kepada masyarakat dan lingkungannya. Jika terjadi sesuatu yang meresahkan, mengorbankan, merugikan atau membawa kesengsaraan bagi masyarakat akibat langsung dan tidak langsung dari kebijakan yang diambil atas dasar free-choice, maka pemerintah wajib mempertanggungjawabkannya kepada masyarakat. Tanggung jawab ini lebih bersifat etis-moral dari pemerintah terhadap rakyatnya. Dengan demikian untuk mewujudkan pemerintahan yang bertanggung jawab sebaiknya memenuhi 
tiga dimensi seperti yang telah dikemukakan pada tinjauan pustaka, yaitu dimensi Acountability, obligation dan cause.

Terkait dengan dimensi obligasi dan cause, dalam tanggung jawab birokrasi pemerintahan, diakui oleh Kepala Dinas Tata Ruang dan Bangunan Kota Makassar bahwa dalam melaksanakan tugas sebagai Kepala Dinas Tata Ruang dan Bangunan Kota Makassar yang merupakan tugas perpanjangan tangan Walikota Makassar kadang masih diperhadapkan pada berbagai kendala, misalnya masih adanya pegawai yang tidak memperlihatkan keihklasan dalam memberikan pelayanan kepada masyarakat dan masih ada pegawai yang bekerja tidak sepenuh hati.

Berdasarkan hasil penelitian peneliti, bahwa keikhlasan dalam bekerja, petugas pelayanan dalam memberikan layanan kepada masyarakat belum optimal, sebagaimana yang diharapkan masyarakat. Ketidak pedulian petugas layanan terhadap masyarakat masih sering dijumpai, terutama dalam mengatasi keluhan karena kelambanan proses penyelesian kebutuhan layanan yang disampaikan. Demikian halnya dengan permasalahan ketidakadilan dalam pelayanan seringkali muncul, yang membuat masyarakat merasa kecewa terhadap perlakuan aparat pelayanan, seperti yang dikemukakan salah seorang informan dari unsur masyarakat Anwar, yang mengatakan bahwa birokrasi pemerintahan pada Dinas Tata Ruang dan Bangunan Kota Makassar belum memperlihatkan keihklasan dan keadilan dalam memberikan pelayanan kepada masyarakat. Lebih lanjut informan lain dari unsur masyarakat, ARIF , berpendapat bahwa:

Bentuk tanggungjawab pemerintah melalui para petugas pelayanan perizinan terletak pada sejauhmana mereka mau tau keluhan-keluhan masyarakat apabila masyarakat yang mengurus surat Izin Mendirikan Bangunan mengalami kendala dalam pengurusan surat izin tersebut, bukannya masyarakat didiamkan saja tanpa adanya reaksi sedikitpun dari para pelayanan perizinan. (hasil wawancara)

Pendapat ARIF tersebut itulah makna dari tanggung jawab dari aparat pemerintah dalam upaya meningkatkan pelayanan kepada masyarakat sebagai penerima layanan. Tanggungjawab aparat dalam menjalankan tugas pelayanan dinilai tidak saja hanya pada saat setelah melakukan kegiatan pelayanan, tetapi juga dinilai pada saat sedang menjalankan tugas pelayanan. Karena itu, sebelum menjalankan tugas pelayanan perlu diperhatikan apa saja yang menjadi kewajiban dan tanggung jawab pribadi yang harus dijalankan.

Bagaimana bentuk tanggung jawab dari pihak petugas pelayan perizinan atau birokrasi pemerintahan?. Hasil penelitian penulis menunjukkan bahwa tanggung jawab birokrasi pemerintahan dalam memberikan pelayanan yang berkualitas, masih sebatas pada tanggungjawab berdasarkan apa yang tertulis sesuai aturan (dimensi accountability), dan belum menyentuh sepenuhnya tanggungjawab otonom dan etis moral (dimensi obligasi dan dimensi cause).

\section{Responsivitas Birokrasi Pemerintahan}

Salah satu aspek perilaku birokrasi pemerintahan dalam memberikan pelayanan kepada masyarakat adalah responsivitas atau daya tanggap birokrasi pemerintahan terhadap berbagai kebutuhan dan permasalahan yang terjadi dalam masyarakat. Dalam konteks pelayanan perizinan, responsivitas birokrasi pemerintahan menjadi sangat dibutuhkan masyarakat ketika masyarakat membutuhkan pelayanan perizinan yang berkualitas. Secara singkat responsivitas disini menunjuk pada keselarasan program dan kegiatan pelayanan dengan kebutuhan dan aspirasi masyarakat. Responsivitas sebagai salah satu indikator kinerja karena responsivitas secara langsung menggambarkan kemampuan organisasi 
publik dalam menjalankan misi dan tujuannya, terutama untuk memenuhi kebutuhan masyarakat.

Untuk melihat perilaku birokrasi yang responsive dalam pelayanan dapat diukur dari ketepatan dan kecepatan birokrat dalam memberikan pelayanan, dimana dari hasil wawancara penulis dengan kepala Bidang perizinan, mengatakan, bahwa:

Dalam memberikan pelayanan kepada masyarakat dilihat dari aspek ketepatan, bahwa pengajuan IMB jika berkasnya lengkap maka waktu penyelesaian izin tersebut normalnya Cuma $6-12$ hari kerja, dan inilah bentuk pelayanan prima yang diberikan kepada masyarakat, kecuali apabila pengajuan berkasnya tidak lengkap, maka waktu penyelesaian IMB 89nsu lewat dari 6-12 hari kerja. (hasil wawancara)

Selain dari responsivitas yang diukur dari ketepatan yang merupakan salah satu ukuran dalam memberikan pelayanan kepada masyarakat, penulis juga menanyakan kepada Kepala Bidang Perizinan tentang kecepatan yang diberikan dalam pelayanan, di mana dari hasil wawancara peneliti dijelaskan bahwa:

Tingkat kepuasan masyarakat dalam kecepatan pelayanan sudah mencapai 80 $\%$ tingkat kepuasan masyarakat dari pelayanan yang diberikan birokrat. Terbukti dengan beberapa penghargaan yang diterima, dan target yang tercapai dari sisi pelayanan, sehingga kami diberi penghargaan. (hasil wawancara).

Untuk mengetahui responsivitas dalam operasionalnya baik pada ketepatan dan kecepatan yang menjadi alat ukur kinerja pelayanan pemerintahan kepada masyarakat, sebaiknya memperhatikan indikator-indikator sebagai berikut; (1) keluhan dari masyarakat dalam memperoleh pelayanan; (2) Sikap aparat birokrasi dalam merespon keluhan dari masyarakat; (3) perbaikan penyelenggaraan pelayanan pada masa mendatang; (4) memberikan kepuasan pelayanan kepada masyarakat; menggunakan 89 nsure pelayanan yang berlaku.

Masih terkait dengan responsivitas pada dimensi ketetapan dan kecepatan, berdasarkan hasil wawancara peneliti dengan informan dari unsur birokrat kepala Seksi Administrasi Perizinan memberi tanggapan bahwa:

Dalam melayani pemohon IMB, kami selalu tepat, karena ketepatan dalam memberikan pelayanan harus sesuai dengan aturan yang ada, misalnya pemohon yang mengajukan IMB harus melampirkan persyaratan administrasi yang telah ditetapkan dalam formulir, yaitu membuat surat permohonan, foto copi KTP, Sertifikat rumah, kepemilikan tanah, dan gambar / dena rumah yang akan dimohonkan. Apabila berkas yang diajukan pemohon tidak lengkap, maka berkas tersebut dikembalikan untuk dilengkapi, dengan penyampaiannya melalui surat atau melalui telepon. (hasil wawancara)

Apa yang dikemukakan oleh Kepala Seksi Administrasi Perizinan, sejalan dengan hasil wawancara peneliti dengan salah seorang pejabat stuktural di Kantor Pelayanan Administrasi Perizinan yang menjabat sebagai Kepala Seksi Penerbitan Izin, yang menuturkan bahwa:

Dilihat dari ketepatan dan kecepatan waktu pelayanan, Kantor perizinan tepat dalam memberikan pelayanan, karena Cuma butuh waktu $2-6$ hari kerja surat IMB tersebut 89nsu selesai., apabila berkas yang diajukan pemohon tidak bermasalah. (hasil wawancara)

Dengan memperhatikan hasil wawancara penulis dengan para informan dar unsur birokrat sebagai pelayan pada umumnya mengatakan bahwa responsivitas birokrasi pemerintahan dilihat dari dimensi ketepatan dan kecepatan dalam memberikan pelayanan semua mengatakan sesuai dengan aturan dan mekanisme yang telah digariskan oleh Walikota Makassar yang tertuang dalam peraturan Walikota Makassar nomor. 14 
Tahun 2005, tentang tata cara pemberian izin IMB di Kota Makassar, adapun jika terjadi kendala dalam pngurusan IMB itu adalah kesalahan yang dilakukan pemohon sendiri dengan tidak melengkapi persyaratan administrasi yang telah ada dalam formulir permohonan IMB. Menurut para birokrat, bahwa kendala yang terjadi biasanya menyangkut masalah teknis dilapangan misalnya pengajuan gambar yang merupakan lampiran dalam pengurusan IMB tidak sesuai dengan rooling yang telah ditentukan, atau peruntukan lahan yang diajukan tidak sesuai.

\begin{tabular}{lllr}
\multicolumn{1}{c}{ Untuk lebih memahami } & tentang \\
ketepatan dan & kecepatan & dalam \\
memberikan & pelayanan, & peneliti
\end{tabular} memperoleh data dari hasil wawancara peneliti dengan informen dari unsur masyarakat sebagai pemohon IMB Anwar, yang telah mengurus Izin Mendirikan Bangunan menuturkan dari hasil wawancara peneliti tentang ketepatan pengurusan IMB, bahwa:

Ketepatan pelayanan yang diberikan birokrat belum optimal, karena masih sering terjadi dalam pengurusan IMB keterlambatan dalam penyelesaian izin. Walaupun menurut birokrat bahwa penyelesaian izin sudah tepat dilakukan (6-12) hari kerja, itu benar menurut versi birokrat, tetapi dalam kenyataanya tidaklah demikian. Saya pernah mengalami dalam pengurusan IMB, IMB yang yang saya urus ternyata lewat dari 12 hari kerja, dan 90nsure tiap hari saya 90nsure ke Kantor tersebut, tetapi selalu kata janji yang disampaikan kepada saya.. (hasil wawancara)

Jelaslah apa yang dialami Anwar selama mengurus Izin Mendirikan Banguan sangatlah mengecewakan jika dilihat dari segi waktu penyelesian IMB, karena setiap saya menanyakan waktu penyelesaian IMB kurang direnspon dengan baik walaupun saya mengeluh, justru saya sering dengar kata janji-janji, kondisi inilah sehingga saya beranggapan bahwa aparat birokrasi di Kantor Dinas Tata Ruang dan Bangunan Kota Makassar masih kurang memiliki responsivitas sesuai keinginan masyarakat.

Hasil wawancara peneliti dengan Anwar dan didukung oleh Makmur yang mengatakan bahwa:

Dalam pengurusan IMB yang saya alami, jelas petugas layanan kurang memiliki kecepatan dalam memberikan layanan, bahkan yang sering terdengar kata janji kepada masyarakat yang mengurus IMB (hasil wawancara)

Informan lain, Amrin memberi tanggapan tentang ketepatan, dan kecepatan , bahwa:

untuk kedua kategori ini secara umum para birokrat yang bertugas pada pengurusan pelayanan umumnya belum menberi kepuasan kepada masyarakat, baik dari segi ketepatan pelayanan, maupun kecepatan pelayanan dari para petugas layanan, karena saat saya mengurus IMB, seharusnya sudah ada petugas layanan yang menyambut saya, dan menanyakan keperluan apa....., tetapi kenyataannya saya sudah lama berdiri sambil melihat kiri-kanan, tetapi tidak satupun pegawai yang menghampiri saya. Atas pengalaman saya inilah, sehingga saya beranggapan bahwa respon dari para birokrat terhadap masyarakat masih kurang. (hasil wawancara).

Apa yang dikemukakan oleh Informan Amrin menunjukkan bahwa sepertinya pemerintah kurang tanggap dengan keluhan masyarakat. Banyaknya keluhan masyarakat terhadap pelayanan dan tindakan pemerintah dalam menanggapi kebutuhan masyarakat menandakan rendahnya responsivitas pemerintahan sebagai pelayan publik. Untuk merubah image masyarakat tentang hal tersebut, pemerintah perlu menunjukkan sikap dan perilaku yang responsif terhadap kebutuhan masyarakat. Dengan menunjukkan sikap responsif berarti aparat pemerintah sungguh memperhatikan kepentingan dan kebutuhan masyarakat.

Berdasarkan pendapat dari informan unsur birokrat dan informan unsur 
masyarakat yang mengurus IMB, yang cenderung tidak sejalan, maka peneliti berpendapat berdasarkan pengamatan bahwa, dilihat dari responsivitas birokrat (ketepatan dan kecepatan ) dalam pelayanan pengurusan IMB, birokrat masih kurang menampakkan kualitas pelayanan sesuai yang diinginkan masyarakat, karena respon birokrat terhadap keluhan-keluhan masyarakat juga masih kurang dan cenderung berperilaku diskriminatif terhadap pemohon IMB, dan menyalahi konsep responsivitas. Pendapat peneliti tentang responsibilitas birokrat dalam memberikan pelayanan kepada masyarakat sejalan dengan pendapat Dwiyanto (2003: 88) menjelaskan bahwa salah satu masalah dalam pelayanan publik adalah responsivitas pemerintah daerah dalam kaitannya dengan tugas pelayanan pemerintah.

\section{SIMPULAN}

Perilaku birokrasi pemerintahan dalam pelayanan IMB pada Dinas Tata Ruang dan Bangunan Kota Makassar dilihat dari aspek tanggung jawab sudah dilaksanakan dengan baik, walaupun masih sebatas pada tanggung jawab makna acountability (tanggungjawab apa yang tertulis berdasarkan aturan-aturan/tupoksi), dan belum disertai tanggung jawab pada makna obligasi dan makna cause (tanggungjawab otonom dan tanggungjawab etis-moral).

Perilaku birokrasi pemerintahan dalam pelayanan IMB dari aspek responsivitas, menurut birokrat bahwa pelayanan IMB yang diberikan kepada masyarakat dilihat dari ketepatan, kecepatan, sudah dilaksanakan sesuai dengan aturan dalam pengurusan IMB, tetapi tanggapan masyarakat tidaklah demikian, bahkan masyarakat mengeluh terhadap layanan yang diberikan birokrat karena masih adanya praktek diskriminasi dalam pemberian pelayanan.

\section{DAFTAR PUSTAKA}

Bungin, Burhan. 2010. Metode Penelitian Kualitatif. Jakarta: Kencana

Denhardt.J.V and Denhardt, R.B. 2003. The New Public Service: Serving not Steering. London: Armonk. M.E. Sharpe.

Djohan, Djohemansyah dan Milwan. 2007. Etika Pemerintahan. Jakarta: Universitas Terbuka.

Dwiyanto, Agus. Dkk, 2003.Reformasi 2008. Reformasi Birokrasi Publik Di Indonesia. Yokyakarta: Gajah Mada University Press.

Keraf Sonny. 2005. Etika Bisnis. Tuntutan dan relevansinya (edisi baru). Kanisius. Yokyakarta.

Lukman, Sampara. 2003. Manajemen Kualitas Pelayanan (cetakan kedua). Jakarta: STIA-LAN Press

Napitupulu Paimin. 2007. Pelayanan Publik \& Customer Satisfaction. Bandung: Alumni.

Ndraha Taliziduhu. 2005. Kybernologi. Sebuah Konstruksi Ilmu Pemerintahan. Jakarta: Rineka Cipta

----------, 2003. Budaya Organisasi. Jakarta: Rineka Cipta.

Smith, BC. 1985. Decentralization, The Territorial Dimension of the State. London: George Allen and Unwin.

Spiro, Herberr,J. 1969. Responsibility in Government. New York: Van Nostrand Reinhold Company.

Subarsono. A.G. 2006. Pelayanan Publik yang efisien, Responsif dan non Partison. Yokyakarta: Gadjahmada University Press.

Sugiyono. 2009. Memahami Penelitian Kualitatif, Bandung: Alfhabetha.

Undang-Undang Pelayanan Publik. 2009. Undang-undang Republik 
Indonesia Nomor 25 Tahun 2009. Bandung: Fokusmedia.

Widodo, Joko, 2001. Good Governance:

Telaah dari Dimensi

Akuntabilitas dan Kontrol

Birokrasi Pada Era

Desentralisasi dan Otonomi

Daerah. Surabaya: Ihsan

Cendekia.

Peraturan Daerah No. 14 Tahun 2005.

Tentang tata Cara pemberian Izin Pemerintah Kota Makassar.

Peraturan Daerah No. 15 Tahun 2004.

Tentang Izin Mendirikan

Bangunan. Makassar.

Keputusan Menteri Aparatur Negara

(PAN) No. 81 Tahun 1999.

Tentang Pelayanan Yang

Berkualitas. Jakarta: Menpan

Keputusan Menteri Aparatur Negara

(PAN) No. 63 Tahun 2003.

Tentang Pelayanan Yang

Berkualitas. Jakarta: Menpan.

Undang-Undang Dasar Negara republik Indonesia Tahun 1945. Tujuan Pembentukan Negara. Jakarta: Indonesia legal Center Publising.

Undang-Undang No. 32 Tahun 2004. Tentang Pemerintahan Daerah. Jakarta: Menpan

Undang-Undang No. 25 Tahun 2009. Tentang Pelayanan Publik Dan Badan Layanan Umum 2010. Jakarta: Tamita Utama. 